The University of Southern Mississippi

The Aquila Digital Community

Faculty Publications

3-1-1999

\title{
A Forty-Niner from Tennessee: The Diary of Hugh Brown Heiskell
}

John D. W. Guice

University of Southern Mississippi, John.Guice@usm.edu

Follow this and additional works at: https://aquila.usm.edu/fac_pubs

Part of the History Commons

\section{Recommended Citation}

Guice, J. D. (1999). A Forty-Niner from Tennessee: The Diary of Hugh Brown Heiskell. Journal of the Early Republic, 19(1), 153-155.

Available at: https://aquila.usm.edu/fac_pubs/4609

This Book Review is brought to you for free and open access by The Aquila Digital Community. It has been accepted for inclusion in Faculty Publications by an authorized administrator of The Aquila Digital Community. For more information, please contact Joshua.Cromwell@usm.edu. 
Native Americans, the struggle for recognition and rights continues. Those readers seeking an understanding of the background and consequences of the Mexican-American War from a Latino perspective will find a compelling and articulate introduction to contemporary problems in this collection.

John M. Belohlavek, professor of history at the University of South Florida, is the author of several volumes on Jacksonian politics and diplomacy. He is presently writing a biography of Caleb Cushing.

A Forty-niner from Tennessee: The Diary of Hugh Brown Heiskell. Edited by Edward M. Steel. (Knoxville: University of Tennessee Press, 1998. Pp. xxxix, 120. $\$ 30.00$.)

Because of the length and details of his entries, the diary of Hugh Brown Heiskell provides a revealing account of the life of a "forty-niner" on the trail across the plains and mountains to the American River. Heiskell, the fifth of ten children of the owner and editor of the Knoxville Register, attended East Tennessee University and read the law. There were other college men and professionals, including a medical school graduate, in the group from Monroe County who joined a train of twelve wagons, fifty people, and some one hundred draft animals led by Colonel James W. Bicknell from Madisonville, Tennessee. Their guide was Charles Taplin, a veteran of two of John C. Fremont's expeditions.

Kept in a leather-bound ledger, the extant portion of Heiskell's diary begins on August 13, 1849 on the Green River in today's Wyoming and ends on October 21 as they descended into the gold fields from the crest of the Sierra Nevada. A descendent of Hugh Heiskell's sister Susan, editor Edward M. Steel skillfully pieced together a prologue and epilogue from a variety of sources, including family correspondence. The prologue includes biographical data relating to the Tennesseans and their journey from Knoxville to St. Louis to Ft. Laramie. The epilogue offers a brief but vivid picture of the emerging town of Sacramento and the mining camps above it. Here Steel focuses on the community of Weaverville where the "Monroe Mess"-so called because they traveled and ate together on the trail-spent the winter of 1849-50.

Heiskell's diary is typical in that he described the diversity of humanity that comprised the forty-niners and their privation on the trail. His train and others traveling near it included persons in a wide range of age, race, nationality, occupation, education, wealth, ambition, and disposition. Their number included three women and at least four blacks-two free and two slave. As one might expect, there was a sizable contingent of Mexican War 
veterans. On the other hand, Heiskell's account is unique. His powers of observation as well as his literacy were definitely above average. Not only did he have an unusual amount of curiosity, but he had sufficient education to describe flora and fauna and geological formations in terms of the classifications of Linnaeus and Lyell. His father sold his publishing house when Heiskell was a youngster, and the family moved to a large selfsufficient farm that Hugh and his mother once managed briefly. This may explain why Heiskell made numerous observations regarding the landscape and its capacity to sustain various crops and livestock.

At the top of each entry is the day, date, location, and mileage covered that day. Heiskell, as did most diarists, noted the weather and travel conditions. Virtually without fail, he described where and on what they "nooned," and he frequently recorded in some detail the more interesting conversations around the camp fire in the evening. One of the more notable discussions, for instance, pertained to the poetry of Lord Byron and the religious preferences of Charles II. Though he mentions the monotony of the trail diet, he also boasts of the more sumptuous meals that they enjoyed that generally included a variety of wild meat, fish, and fowl. Several members of the Monroe Mess were avid anglers as was Heiskell as long as the fish were biting.

While the participation of southerners in the gold rushes of 1849 in California and 1859 in Colorado is well known, this book reinforces this point and reminds readers of the earlier gold rushes in North Carolina and Georgia. Because the Monroe Mess were from Eastern Tennessee, they were particularly interested in and knowledgeable about gold mining. Steel, in the prologue, reveals much about the Southern frontier. Because few historians pay attention to the South as a frontier, the references to activities such as cattle raising and steamboating on the lesser rivers are significant.

While Heiskell commented frequently on encounters with American Indians, he seems not to have been unduly prejudiced against them. Born in 1826, it is not likely that he personally had contact with many Indians, but he is bound to have heard tales of the considerable Indian-white conflict that characterized Tennessee's early history. Nevertheless, his depiction of the Indians varied. At times he saw them as annoying visitors, crafty traders, rustlers of livestock, or dangerous night riders. But he also wrote of them as hard and helpful workers who cut hay, as talented trackers who recovered strayed oxen, as guides, or as providers of berries, fish, and game. Regardless of their roles, Heiskell showed a keen interest in Indian artifacts and culture.

Hugh Heiskell's letters home show that he was an extremely sensitive and affectionate young man who often commented on the beauty of nature. 
In a letter to his younger sister Susan, for instance, he used adjectives such as beautiful, pretty, pleasing, rich, fine, or boundless to describe the scenery. He seemed particularly fond of the word beautiful and he admonished Susan on the importance of education and a cheerful disposition.

The contingent from East Tennessee left St. Joseph on May 23 and arrived at the "first diggings" on October 24, averaging sixteen miles per day. Ironically, Hugh Heiskell died on November 16. Five of the nine companions who left home together died in California, two after careers of considerable prominence and financial success. Three returned to the eastern states. The fate of one remains a mystery.

The six maps of Heiskell's route are quite helpful, and the fifteen illustrations, including recent photographs of notable landmarks, encourage the reader to envision the trail as Heiskell saw it. This book represents a thorough piece of scholarship and a contribution to both Southern and Western history by Steel, an emeritus professor, at West Virginia University.

John D. W. Guice, professor of history at the University of Southern Mississippi, is author of The Old Southwest: Frontiers in Conflict, 17951830, with Thomas D. Clark. He is presently writing a history of the Natchez Trace.

Dorothea Dix: New England Reformer. By Thomas J. Brown. Harvard Historical Studies. (Cambridge: Harvard University Press, 1998. Pp. xv, 422. Illustrations. \$29.95.)

Before the Civil War, Dorothea Dix enjoyed an international reputation as one of the leading reformers in the United States. Even today, her labors to establish and improve asylums and prisons are frequently lauded in textbooks. Many historians have been less kind to Dix, arguing that her benevolence was the result of never mentioned childhood abuse, or objecting to her conservative views on issues like slavery and women's rights. However, this well written and copiously researched work presents a sympathetic and intimate portrait of one of the best-known reformers in antebellum America.

This intimacy is unusual, because Dix gave few details about her earliest experiences. The reticence to discuss her childhood led previous biographers to assume that some event in her early history influenced her personality and motivated her career in reform. Thomas J. Brown chooses not to search for evidence of childhood trauma or abuse. Instead, he makes 